\title{
WE@UT - A Residential Recruitment Program for Women in Engineering
}

\author{
Tricia S. Berry \\ The University of Texas at Austin
}

\begin{abstract}
The Women in Engineering at The University of Texas (WE@UT) program, a two-day in-depth residential program, is designed to increase participant knowledge and understanding of engineering and technology through hands-on, technology-based team projects so well informed and solid educational and career decisions are made. The objectives of this program are (1) to encourage young women to explore engineering as a career choice; (2) to expose young women to technology across engineering disciplines and to build confidence in using technology; (3) to expose young women to female engineering role models (students, faculty, and industry professionals); (4) to establish an ongoing support network for young women interested in learning about engineering careers; and (5) to introduce young women to a university environment. The overall goal is to increase the enrollment of women in engineering programs at The University of Texas at Austin (UT).
\end{abstract}

The pilot WE@UT program, held in July 2001 in conjunction with The University's on-campus honor student recruitment program, had an enrollment of 73 women out of 549 students invited to participate. Invited students had indicated an interest in either engineering or natural science on PSAT, SAT, or ACT tests. According to UT admissions information, 78 percent of those who attended WE@UT applied to UT compared to 32 percent of those who were invited but did not attend. In addition, 55 percent of those who attended WE@UT applied to the College of Engineering at UT compared to 6 percent of those who were invited but did not attend. By providing the participants with the opportunity to explore engineering, the Women in Engineering Program (WEP) at UT contributed to increasing the number of female students entering into engineering programs at UT compared to those female students who did not participate in the WE@UT program.

\section{Introduction}

The Women in Engineering Program at The University of Texas at Austin's WE@UT program is a two-day residential program designed to increase participant knowledge and understanding of engineering and technology through faculty presentations, student mentorship, and hands-on, technology-based team projects so well informed and solid educational and career decisions are made. Rising high school senior women who have indicated an interest in engineering or the sciences and who are invited to The University's Honors Colloquium, an on-campus honor student recruitment program, are invited to participate in WE@UT prior to the start of the Honors Colloquium. By limiting participation to this invited group of students, WEP is able to focus its efforts on recruiting outstanding students with higher than average SAT scores and class 
ranks. WE@UT is the first program of its kind at The University where collaboration with the Honors Program and an extension to the Honors Colloquium program are offered. By WEP collaborating with The University's Honors Program, both the College of Engineering and The University benefit by providing an increasingly personalized recruitment effort for outstanding women and WEP benefits by having WE@UT associated with a well-established University-wide recruitment initiative.

As stated in its Strategic Plan, the College of Engineering's overall objective is to be, and to be recognized as, the best public engineering college in the nation ${ }^{1}$. One of the goals of the College of Engineering critical in meeting the strategic objective is to recruit, nurture, and retain outstanding students. While the number of students pursuing and completing undergraduate engineering degrees has been on the decline since the middle 1980's nationwide ${ }^{2}$, enrollment at UT is limited and the College of Engineering is not necessarily striving to increase the number of students to meet the goal. The College is striving to increase the quality of the student body and is recruiting National Merit Finalists and students with high SAT scores more heavily. The Women in Engineering Program contributes to this College goal and effort by offering programs such as WE@UT that target high-potential students interested in engineering or science.

WEP's goal is to increase the percentage of women enrolled in and graduating from the College of Engineering. Degrees conferred to women in the College of Engineering at The University of Texas at Austin (UT) have been fairly constant since 1997 at approximately 21 percent of the total $^{3}$. With limited enrollment, one way to increase the percentage of women enrolled in engineering at UT is to increase the number of honors level women applying to and enrolling in the College of Engineering at UT. WE@UT serves as a means to accomplish this for WEP in the same manner as it contributes to meeting the College's goal.

WE@UT was piloted in July 2001 with 73 participants. The stated WE@UT objectives were met and the percent enrollment of women in engineering was higher for program participants than nonparticipants. Lessons learned were incorporated into the schedule and planning for the continuation of the program. The second WE@UT was held in July 2002 with 79 participants.

\section{Pilot Program Overview}

WE@UT was designed to provide students with information about engineering as a major choice and a career choice so that they may make better informed decisions in the college application process. Shown by the results of the "American Perspectives on Engineers and Engineering" Harris Poll commissioned by the American Association of Engineering Societies (AAES), the public is unaware of the contributions that engineers make to society ${ }^{4}$. With 78 percent of women surveyed feeling they are not informed about engineers or engineering compared to 61 percent of Americans as a whole, outreach and recruitment programs must provide an overview of the field and showcase the variety of engineering career options ${ }^{5}$.

The objectives of WE@UT are (1) to encourage young women to explore engineering as a career choice; (2) to expose young women to technology across engineering disciplines and to build confidence in using technology; (3) to expose young women to female engineering role models (students, faculty, and industry professionals); (4) to establish an ongoing support network for 
young women interested in learning about engineering careers; and (5) to introduce young women to a university environment. The overall goal is to increase the enrollment of women in engineering programs at The University of Texas at Austin (UT).

\section{Planning and Preparation}

The planning and preparation for WE@UT was coordinated with UT's Honors Colloquium efforts. Some of the key items were as follows:

- Coordinate invitation letter with UT's Honors Program

- Interview and hire Program Assistants (undergraduate and graduate female engineering students who assist with the program administration)

- Secure volunteers and presenters and communicate roles and responsibilities

- Secure spaces on campus for activities

- Secure room and board for participants and program assistants with UT's Honors Program

- Invite representatives from corporate supporters and request participant giveaways

- Create online registration process

- Confirm registrations and provide information in conjunction with UT's Honors Program

\section{Budget}

The budget for WE@UT was just under \$10,000 with funding support from three corporate partners. In addition, with the Honors Program collaboration, WEP was able to insert WE@UT materials into Honors Colloquium mailings, thus eliminating these mailing expenses. The budget included room and board for participants, Program Assistant salaries and room and board, supplies, mailings, and meals for volunteers. Funds were raised so that the program was free to all participants and no student would be at an economic disadvantage. Corporate partners were recognized on allWE@UT publications, on the WE@UT t-shirt provided to all participants, staff, and volunteers, and in various presentations throughout the program. Table 1 details the final expenses of the pilot program.

Table1.WE@UT 2001 Pilot Program Expenses.

\begin{tabular}{|l|r|}
\hline \multicolumn{1}{|c|}{ Item } & \multicolumn{1}{|c|}{ Expense } \\
\hline Room and Board (12 Program Assistants and 73 Participants @ \$75 each) & $\$ 6375.00$ \\
\hline Program Assistant Wages (12@\$75 each) and Training & $\$ 1000.00$ \\
\hline Copies for mailings and hand-outs & $\$ 250.00$ \\
\hline Volunteer and Participant T-shirts and Supplies for Activities & $\$ 1500.00$ \\
\hline Meals for Volunteers & $\$ 150.00$ \\
\hline \hline TOTAL & $\$ \mathbf{9 2 7 5 . 0 0}$ \\
\hline
\end{tabular}

\section{Schedule and Activities}

The WE@UT schedule was set in an effort to maximize exposure to engineering, thus virtually no free time was available for the participants. The total time with participants was 25.5 hours from 3:00 p.m. on Day 1 through 4:30 p.m. on Day 2. Activities were designed to be highly hands-on, team oriented, participative, and informative. Activities, ranging from faculty and industry presentations to meals with mentors to a hands-on team challenge, are described in Table 2 and 
Table 3. In addition, the Associate Dean for Student Affairs led a question and answer session for the parents with representatives from academic advising, WEP, the Equal Opportunity in Engineering Program, and the Scholarship Program.

Table 2. WE@UT Pilot Program Schedule-Day 1.

\begin{tabular}{|c|c|c|}
\hline Time & Activity & Description \\
\hline $1-3$ p.m. & $\begin{array}{l}\text { Check In: Select } \\
\text { Sessions and Engineer } \\
\text { for "Lunch-Date" }\end{array}$ & $\begin{array}{l}\text { All session topics and engineer biographies are } \\
\text { available for review and selection. }\end{array}$ \\
\hline $3-3: 30$ p.m. & Welcome Reception & $\begin{array}{l}\text { Parents and participants are welcomed by the VP for } \\
\text { Student Affairs, College of Engineering Dean, WEP } \\
\text { Director and WEP Program Coordinator. }\end{array}$ \\
\hline $3: 30-4$ p.m. & $\begin{array}{l}\text { Introduction to Teams } \\
\text { and Program } \\
\text { Assistants }\end{array}$ & $\begin{array}{l}\text { Participants break out into teams and meet their team } \\
\text { members and engineering student Program Assistant. }\end{array}$ \\
\hline $4-5$ p.m. & Keys to Success & $\begin{array}{l}\text { Participants are given tips on working effectively in } \\
\text { teams with concepts reinforced through role playing. }\end{array}$ \\
\hline $5-6$ p.m. & Learning Styles & $\begin{array}{l}\text { Participants take learning style assessment and } \\
\text { appropriate, style-specific study habits are introduced } \\
\text { and described for future implementation. }\end{array}$ \\
\hline $6-7: 30$ p.m. & $\begin{array}{l}\text { Dinner - Meet your } \\
\text { E-mail Mentor }\end{array}$ & $\begin{array}{l}\text { Participants meet their assigned engineering student } \\
\text { E-mail mentor, a resource to them after WE@UT. }\end{array}$ \\
\hline 7:30 - 8 p.m. & UT and WEP & $\begin{array}{l}\text { Engineering students describe the programs and } \\
\text { activities coordinated by the Women in Engineering } \\
\text { Program and benefits of participation. }\end{array}$ \\
\hline $8-9$ p.m. & $\begin{array}{l}\text { Engineering is...? } \\
\text { Development / } \\
\text { Presentations }\end{array}$ & $\begin{array}{l}\text { Engineering students from each major present on } \\
\text { what career options may be within their field and } \\
\text { discuss what they feel their field is all about. } \\
\text { Engineering students present one of the classroom } \\
\text { projects they have completed in their studies. }\end{array}$ \\
\hline $9-10$ p.m. & $\begin{array}{l}\text { Team Challenge: } \\
\text { Introduction, Rules, } \\
\text { and Design Stage }\end{array}$ & $\begin{array}{l}\text { Participants are introduced to the engineering design } \\
\text { challenge they will complete the following day. } \\
\text { Participants will be designing and constructing a } \\
\text { cardboard bridge to span the gap from one end of a } \\
\text { kiddie play pool to the other while attempting to } \\
\text { maximize the load it will withstand. }\end{array}$ \\
\hline $10-11$ p.m. & $\begin{array}{l}\text { Texas Dragon Dance } \\
\text { Team }\end{array}$ & $\begin{array}{l}\text { One of the student organizations performs their } \\
\text { Dragon Dance in full costume for entertainment and } \\
\text { break purposes. Participants are introduced to the } \\
\text { limitless opportunities within student organizations. }\end{array}$ \\
\hline $11-11: 30$ p.m. & $\begin{array}{l}\text { Day } 1 \text { Team } \\
\text { Debriefing }\end{array}$ & $\begin{array}{l}\text { Participants meet in their team with their program } \\
\text { assistant to discuss on the day's activities. }\end{array}$ \\
\hline
\end{tabular}


Table 3. WE@UT Pilot Program Schedule-Day 2.

\begin{tabular}{|c|c|c|}
\hline Time & Activity & Description \\
\hline $7-8$ a.m. & Breakfast & \\
\hline $8-9$ a.m. & $\begin{array}{l}\text { Ford Motor Company } \\
\text { Presentation }\end{array}$ & $\begin{array}{l}\text { WE@UT sponsor presentation on crash test } \\
\text { dummies }\end{array}$ \\
\hline $9-9: 30$ a.m. & Gather Materials & $\begin{array}{l}\text { Teams gathered their materials for their Team } \\
\text { Challenges later in the day }\end{array}$ \\
\hline 9:30 - 10 a.m. & Details on Sessions & Overview of Engineering Sessions \\
\hline $10-11$ a.m. & Engineering Session 1 & $\begin{array}{l}\text { Participants selected from various engineering } \\
\text { faculty presentations }\end{array}$ \\
\hline 11 a.m. - noon & Engineering Session 2 & $\begin{array}{l}\text { Participants selected from various engineering } \\
\text { faculty presentations }\end{array}$ \\
\hline Noon - 1 p.m. & $\begin{array}{l}\text { Lunch with Your } \\
\text { Engineer! }\end{array}$ & $\begin{array}{l}\text { Participants had lunch with engineers from the } \\
\text { local community }\end{array}$ \\
\hline $1-2$ p.m. & $\begin{array}{l}\text { Tea Debriefing with } \\
\text { Engineer }\end{array}$ & $\begin{array}{l}\text { Teams shared their Team Challenge ideas and } \\
\text { brainstorms with their industry engineer }\end{array}$ \\
\hline $2-3$ p.m. & $\begin{array}{l}\text { Team Challenge - } \\
\text { Construction Stage }\end{array}$ & $\begin{array}{l}\text { Teams implement their bridge design. Time is } \\
\text { used to construct their bridge from their design. }\end{array}$ \\
\hline 3-4 p.m. & $\begin{array}{l}\text { Team Challenge - } \\
\text { Testing Stage }\end{array}$ & $\begin{array}{l}\text { One team at a time tests their bridge. The team } \\
\text { whose bridge withstands the maximum load wins. } \\
\text { Teams present their ideas on how they could } \\
\text { improve their bridge. }\end{array}$ \\
\hline $4-4: 30$ p.m. & WE@UT Wrap Up & $\begin{array}{l}\text { Participants filled out feedback forms and received } \\
\text { final information }\end{array}$ \\
\hline 4:30-5:30 p.m. & $\begin{array}{l}\text { Honors Colloquium } \\
\text { Cohort Meeting }\end{array}$ & $\begin{array}{l}\text { Participants participated in the kick-off to the } \\
\text { Honors Colloquium }\end{array}$ \\
\hline
\end{tabular}

\section{Pilot Program Assessment}

The WE@UT pilot program was a success by all measures. Program objectives and the overall goal of WE@UT to increase the enrollment of women in engineering programs at The University of Texas at Austin (UT) were met.

\section{Objectives Assessment}

The program was designed with the five program objectives in mind. All objectives of the WE@UT program were met as can be seen in the Table 4.

\section{Participant Feedback}

Overall, participants were satisfied with the program content and the information that was shared. The engineering sessions, consisting of faculty presentations and demonstrations, were rated the highest of all the WE@UT activities. Participants rated the interactions with the industry engineers and the engineering students highly. Participants were least interested in the Keys to Success and Learning Styles sessions and commented that they had been introduced to these concepts already. They felt that the information was overwhelming - too much information covered in too short an amount of time. Active, hands-on or interactive sessions were favored over passive, lecture-style presentations. 
Table 4. WE@UT Objectives Assessment.

\begin{tabular}{|l|l|}
\hline Objective & Assessment \\
\hline $\begin{array}{l}\text { (1) To encourage young women to } \\
\text { explore engineering as a career choice }\end{array}$ & $\begin{array}{l}\text { Pre- and post-program mailings as well as activities } \\
\text { throughout the program carried the theme of } \\
\text { encouraging engineering as a choice }\end{array}$ \\
\hline $\begin{array}{l}\text { (2) To expose young women to } \\
\text { technology across engineering } \\
\text { disciplines and to build confidence in } \\
\text { using technology }\end{array}$ & $\begin{array}{l}\text { Participants were exposed to each of the engineering } \\
\text { disciplines at UT through presentations, tours, or } \\
\text { activities; Participants learned about and/or practiced } \\
\text { using various technology such as ROBOLAB } \\
\text { activities in }\end{array}$ \\
\hline $\begin{array}{l}\text { (3) To expose young women to female } \\
\text { engineering role models (students, } \\
\text { faculty, and industry professionals) }\end{array}$ & $\begin{array}{l}\text { Engineering students served as E-mail mentors and } \\
\text { Program Assistants; engineering faculty served as } \\
\text { presenters; and industry professionals served as mentors } \\
\text { and presenters }\end{array}$ \\
\hline $\begin{array}{l}\text { (4) To establish an ongoing support } \\
\text { network for young women interested } \\
\text { in learning about engineering careers }\end{array}$ & $\begin{array}{l}\text { Participants left the program with an engineering } \\
\text { student E-mail mentor, an industry professional contact, } \\
\text { and contact information for each of the 12 Program } \\
\text { Assistants; E-mail contact was maintained with } \\
\text { participants in the months following the program by } \\
\text { both the E-mail mentors and WEP }\end{array}$ \\
\hline $\begin{array}{l}\text { (5) To introduce young women to a } \\
\text { university environment }\end{array}$ & $\begin{array}{l}\text { Participants were housed in the dorm, ate at the dorm } \\
\text { cafeteria, and visited engineering classrooms and labs }\end{array}$ \\
\hline
\end{tabular}

\section{Admissions and Enrollment Results}

The overall goal of WE@UT was to increase the enrollment of women in engineering programs at The University of Texas at Austin (UT). By comparing the study interests of participants prior to the program to the majors students selected on applications for admission to UT, it was determined that the enrollment of women in engineering was increased out of the WE@UT participant pool.

Of the 73 participants, engineering was the collegiate study interest prior to WE@UT for 48 percent of the participants. The first-choice interests for the remaining 52 percent of the participants included Natural Sciences, Liberal Arts, Architecture, Pre-med, Business, Education, Communication, Computer Sciences, or Undecided/Unspecified. Applications for admission to UT showed that 55 percent of the WE@UT participants selected engineering as a major, an increase in engineering interest from before WE@UT. For those who were invited and did not attend WE@UT, 21 percent had indicated an engineering interest while only 6 percent applied for admission in engineering at UT. For WE@UT participants, 23 percent enrolled at UT in engineering for the Fall 2002 semester while only 12 percent of those who did not attend, yet indicated engineering as their major of interest, enrolled at UT in engineering. For WE@UT participants, $100 \%$ of those enrolled at UT in engineering for the Fall 2002 semester were retained in engineering through two semesters. The admissions and enrollment data are summarized in Table 5 below. 
Table 5. Fall 2002 Admissions and Enrollment Data

\begin{tabular}{|c|c|c|c|c|c|c|}
\hline & \multicolumn{3}{|c|}{ 2001 WE@UT Participants } & \multicolumn{3}{|c|}{2001 WE@UT Non-Participants } \\
\hline & Number & $\begin{array}{c}\text { Percent } \\
\text { of Total } \\
\text { Pool }\end{array}$ & $\begin{array}{l}\text { Percent of } \\
\text { Pool with } \\
\text { Engineering } \\
\text { Interest }\end{array}$ & Number & $\begin{array}{c}\text { Percent } \\
\text { of Total } \\
\text { Pool }\end{array}$ & $\begin{array}{l}\text { Percent of } \\
\text { Pool with } \\
\text { Engineering } \\
\text { Interest }\end{array}$ \\
\hline Total Pool & 73 & N/A & $\mathrm{N} / \mathrm{A}$ & 476 & N/A & $\mathrm{N} / \mathrm{A}$ \\
\hline $\begin{array}{l}\text { Engineering interest } \\
\text { prior to WE@UT }\end{array}$ & 35 & $48 \%$ & N/A & 102 & $21 \%$ & N/A \\
\hline $\begin{array}{l}\text { Applications for } \\
\text { admission to UT }\end{array}$ & 57 & $78 \%$ & N/A & 153 & $32 \%$ & N/A \\
\hline $\begin{array}{l}\text { Enrolled in UT Fall } \\
2002\end{array}$ & 22 & $30 \%$ & N/A & 57 & $12 \%$ & N/A \\
\hline $\begin{array}{l}\text { Applications for } \\
\text { admission to UT's } \\
\text { College of Engineering }\end{array}$ & 40 & $55 \%$ & $114 \%$ & 30 & $6 \%$ & $29 \%$ \\
\hline $\begin{array}{l}\text { Enrolled in UT's } \\
\text { College of Engineering } \\
\text { Fall } 2002\end{array}$ & 17 & $23 \%$ & $49 \%$ & 12 & $3 \%$ & $12 \%$ \\
\hline $\begin{array}{l}\text { Enrolled in UT's } \\
\text { College of Engineering } \\
\text { Spring } 2003 \text { (retained } \\
\text { for two semesters in } \\
\text { engineering) }\end{array}$ & 17 & $23 \%$ & $49 \%$ & \multicolumn{3}{|c|}{ Data not available } \\
\hline
\end{tabular}

\section{Lessons Learned}

WEP has significant experience with residential programs and recruitment initiatives. This contributed to the success of the program and the limited number of challenges experienced throughout the planning stages and the program itself. Some of the key lessons learned after the WE@UT pilot program was completed were as follows:

- Collaborating with another entity on campus creates wonderful synergies; however it required a shifting of the WE@UT timeline since WEP was not leading the overall effort. WEP should be prepared for shorter lead times than desired.

- It would have been helpful to have one student assistant not assigned to a team so that she could assist in overall program logistics along with the WEP Program Coordinator.

- The demand for the program exceeded the budget thus additional funding should be secured so all interested students may participate.

- It is difficult to get through a lot of material in 25.5 hours and the participants were overloaded with information and exhausted by the busy schedule. Lengthening the program by one day would allow for more free time for participants along with additional time for showcasing the field of engineering.

- It is important to track student admissions and student enrollment for all invited students in order to best measure program effectiveness.

Proceedings of the 2003 American Society for Engineering Education Annual Conference \& Exposition Copyright $@$ 2003, American Society for Engineering Education 


\section{Program Continuation}

Based on the success of the WE@UT pilot program in 2001, WEP continued WE@UT in 2002 with modifications and improvements. The number of students accepted into the program increased to 100 students who will be applying for Fall 2003 admission (79 students actually participated). Program feedback has been compiled; however final admissions and enrollment results will not be known until the Fall 2003 begins and enrollment is complete.

\section{Program Modifications}

Objectives for the 2002 WE@UT program remained the same as for the 2001 pilot program. Activities were varied slightly based on feedback from participants in the pilot program. An introduction to the engineering problem solving method was added along with a College of Engineering Prospective Student Session administered by one of the academic advisors in the College. Team projects were changed from one more comprehensive project to four shorter hands-on engineering challenges. Participants in 2002 were not assigned an engineering student Email mentor; however they were given an additional opportunity to interact with engineers from industry at dinner on the first day.

\section{Participant Feedback}

As with the pilot program, participants were satisfied with the program content and the information that was shared. The engineering sessions, consisting of faculty presentations and demonstrations, were once again rated the highest of all the WE@UT activities. Participants rated the interactions with the industry engineers and the engineering students highly. Participants were least interested in the engineering problem solving method session and commented that they had been introduced to these concepts already. As in the pilot, they felt that the information was overwhelming - too much information covered in too short an amount of time. When participants were asked if they felt they had a better understanding of engineering career opportunities available, 86 percent answered "yes" and 6 percent answered "somewhat" with 59 percent commenting on an increase in understanding of the diversity of the engineering field and the career opportunities available.

\section{Admissions Application Results}

Of the 79 participants, engineering was the collegiate study interest for 51 percent of the participants prior to the 2002 WE@UT program. Applications for admission to UT as of March 25, 2003 show that 49 percent of the WE@UT participants have selected engineering as a major and 33 percent of the WE@UT participants have been admitted to the College of Engineering. For those who were invited and did not attend WE@UT, 17 percent had indicated an engineering interest while only 7 percent have applied for admission and been admitted to the College of Engineering at UT as of March 25, 2003. Admissions information for 2002 WE@UT participants and non-participants are shown in Table 6. 
Table 6. Fall 2003 Admissions Data as of March 25, 2003

\begin{tabular}{|l|c|c|c|c|c|c|}
\hline & \multicolumn{2}{|c|}{2002 WE@UT Participants } & \multicolumn{2}{c|}{2002 WE@UT Non-Participants } \\
\hline & Number & $\begin{array}{c}\text { Percent } \\
\text { of Total } \\
\text { Pool }\end{array}$ & $\begin{array}{c}\text { Percent of } \\
\text { Pool with } \\
\text { Engineering } \\
\text { Interest }\end{array}$ & Number & $\begin{array}{c}\text { Percent } \\
\text { of Total } \\
\text { Pool }\end{array}$ & $\begin{array}{c}\text { Percent of } \\
\text { Pool with } \\
\text { Engineering } \\
\text { Interest }\end{array}$ \\
\hline Total Pool & 79 & N/A & N/A & 506 & N/A & N/A \\
\hline $\begin{array}{l}\text { Engineering interest } \\
\text { prior to WE@UT }\end{array}$ & 40 & $51 \%$ & N/A & 88 & $17 \%$ & N/A \\
\hline $\begin{array}{l}\text { Applications for } \\
\text { admission to UT }\end{array}$ & 59 & $75 \%$ & N/A & 186 & $37 \%$ & N/A \\
\hline $\begin{array}{l}\text { Applications for } \\
\text { admission to UT's } \\
\text { College of Engineering }\end{array}$ & 29 & $37 \%$ & $73 \%$ & 37 & $7 \%$ & $42 \%$ \\
\hline $\begin{array}{l}\text { Admitted to UT's } \\
\text { College of Engineering }\end{array}$ & 26 & $33 \%$ & $65 \%$ & 34 & $7 \%$ & $39 \%$ \\
\hline
\end{tabular}

\section{A Model for Other University Programs}

WE@UT was the first program within the University to take advantage of the Honors Colloquium synergies. Based on the successes of WE@UT and the interest from participants in attending a College-specific program prior to the Honors Colloquium, other Colleges and University programs are evaluating such initiatives. The first such program to be modeled off of WE@UT, an initiative targeting women in Computer Science through the College of Natural Science, will begin with the Summer 2003 Honors Colloquium.

\section{Conclusions and Future Initiatives}

There are many factors that contribute to students choosing engineering as a major in college. The Women in Engineering Program's WE@UT initiative is a targeted recruitment effort aimed at increasing the number of women majoring in engineering at UT. Given the pool of students invited to The University's Honors Colloquium, the WE@UT program is impacting the number of female students choosing engineering as a major. The female participants, through introduction to the diverse opportunities available within the engineering discipline, are making a more informed decision regarding their choice of major.

The WE@UT program will be offered in the future provided that funding is available and collaboration with the UT Honors Program continues. The demand for the program will likely increase as the program becomes more institutionalized as a precursor to the Honors Colloquium for students interested in engineering or science. The key to future WE@UT success will be the conversion of an increased number of participants to enrolled engineering students at UT.

Future work includes increased analysis of the WE@UT participants through implementation of a pre-survey to assess understanding of engineering as a career option and modification of the postsurvey. In addition, retention of WE@UT participants within the College of Engineering at UT will be evaluated beginning at the conclusion of the 2002-2003 academic year - the first year of college for the 2001 WE@UT pilot program participants.

Proceedings of the 2003 American Society for Engineering Education Annual Conference \& Exposition Copyright @ 2003, American Society for Engineering Education 


\section{References}

1. The University of Texas at Austin, College of Engineering, State of the College of Engineering 2002, Website URL [http://www.engr.utexas.edu/admin/dean/college02.cfm], site visited January 12, 2003.

2. U. S. Department of Education, Digest of Education Statistics, 2001, Website URL [http://nces.ed.gov/pubs2002/digest2001/ch3.asp], site visited January 12, 2003

3. The University of Texas at Austin, Office of Institutional Studies, Website URL

[http://www.utexas.edu/academic/oir/], site visited January 12, 2003

4. The National Academy of Engineering, Harris Poll Reveals Public Perceptions in Engineering, Washington, September 1, 1998, Website URL [http://www.nae.edu/NAE/naehome.nsf/weblinks/NAEW-

4NHMEX?OpenDocument], site visited January 12, 2003

5. Eng, Julie Sheridan, Engineering: In need of a makeover?, Institute of Electrical and Electronics Engineers (IEEE) Spectrum, March 1999.

\section{Biographical Information}

TRICIA BERRY is the Director of the Women in Engineering Program at The University of Texas at Austin. Prior to this role, Tricia was Engineering Scholarship Program and Undergraduate Recruitment Director. She came to UT in July 1999 after six years at The Dow Chemical Company in Freeport, Texas. Tricia received her BS Chemical Engineering degree from UT in May 1993 and her MBA from the University of Houston - Clear Lake in May 1999. 